\title{
Soviet Science as Cultural Diplomacy during the Tbilisi Conference on General Relativity
}

\section{J.-P. Martinez}

For citation: Martinez J.-P. Soviet Science as Cultural Diplomacy during the Tbilisi Conference on General Relativity. Vestnik of Saint Petersburg University. History, 2019, vol. 64, issue 1, pp. 120-135. https://doi.org/10.21638/11701/spbu02.2019.107

Scientific research - in particular, military and nuclear - had proven during the Second World War to have the potential to demonstrate the superiority of a country. Then, its internationalization in the post-war period led to its being considered a key element of cultural diplomacy. In 1968, during the organization of a conference on general relativity and gravitation in Tbilisi, geopolitics and science encountered abruptly. As a consequence of the Third Arab-Israeli War between Israel and the neighboring states of Egypt, Jordan, and Syria in June 1967, diplomatic relations between the USSR and Israel were interrupted. Then, Israeli physicists initially were not invited to join their colleagues in Georgia. Such a political decision provoked a tense crisis that afterwards would affect the institutional organization of the scientific community dealing with the theory of relativity. The present article proposes to examine this episode of the history of science as part of the history of Soviet cultural diplomacy. Indeed, focusing on Soviet actors of the Israeli crisis in 1968, it is possible to better understand the political influences on scientists in the USSR. In this context, of particular interest is the international trajectory of the Head of the local organizing committee of the Tbilisi conference, Vladimir A. Fock. From his example, it is shown in the article that Soviet scientists primarily acted as representatives at the international level and were restricted in their movement. Their actions were under control of their scientific and political authorities.

Keywords: cultural diplomacy, science, general relativity, Vladimir Fock, Dmitri Ivanenko, Tbilisi, Copenhagen.

\section{Советская наука как культурная дипломатия во время конференции об общей теории относительности в Тбилиси}

Ж.-Ф.Мартинес

Для цитирования: Martinez J.-P. Soviet Science as Cultural Diplomacy during the Tbilisi Conference on General Relativity // Вестник Санкт-Петербургского университета. История. 2019. Т. 64. Вып. 1. С. 120-135. https://doi.org/10.21638/11701/spbu02.2019.107

Jean-Philippe Martinez - PhD in Epistemology and History of Science, Postdoctoral Fellow, Federal University of Bahia, Brazil, 40210-340, Salvador - BA, Ondina; Associate Researcher, University Paris 7 - Paris Diderot, France, 75205, Paris cedex 13, Thomas Mann rue 5, Condorcet building, box 7093; jeanphilippe.martinez@gmail.com

Жан-Филипп Мартинес - PhD в эпистемологии и истории науки, постдок, Федеральный университет штата Баия, Бразилия, 40210-340, Сальвадор - ВА, 40210-340, Ондина; науч. сотр., Университет Париж 7 - Париж Дидро, Франция, седекс 13, Париж, здание Кондорсе, а/я 7093, ул. Томаса Манна, 5; jeanphilippe.martinez@gmail.com

(C) Санкт-Петербургский государственный университет, 2019 
Научные исследования, в частности военные и ядерные, доказали во время Второй мировой войны, что они могут продемонстрировать превосходство страны. Поэтому интернационализация в послевоенный период заставила считать их одним из ключевых элементов культурной дипломатии. В 1968 г. во время конференции по общей теории относительности и гравитации, проходившей в Тбилиси, наука и геополитика неожиданно встретились. В результате шестидневной войны в июне 1967, в которой Израилю противостояли такие страны, как Египет, Иордания и Сирия, дипломатические отношения между СССР и Израилем были прерваны. Из-за этого израильским физикам не предложили присоединиться к коллегам на конференции в Грузии. Такое политическое решение вызвало кризис, который в будущем повлиял на институциональную организацию научного сообщества, занимающегося теорией относительности. В этой статье предлагается рассмотреть данный эпизод истории науки как часть истории советской культурной дипломатии. Привлекая внимание к советским участникам конференции, кризис 1968 г. помогает понять свое политическое влияние на ученых в СССР. Поэтому особое внимание в статье уделено международной траектории деятельности главы местного организационного комитета конференции Владимира Фока, чьи архивы особенно ценны. Анализ, проведенный в статье, в частности, показывает, что советские ученые играли в основном роль представителей на международной арене и пользовались весьма ограниченной свободой действий. Они находились под контролем научных и политических властей.

Ключевые слова: культурная дипломатия, наука, общая теория относительности, Владимир Фок, Дмитрий Иваненко, Тбилиси, Копенгаген.

In 1950, during the race for nuclear weapons, the Dane Niels Bohr - emblematic figure in world physics ${ }^{1}$ - advocated a full exchange of scientific information among nations, an "open world" as he called it ${ }^{2}$. For him, it was the only way to keep the humanity peaceful. Then, in 1956, when Nikita Khrushchev at the $20^{\text {th }}$ Congress of the Communist Party officially declared the idea of peaceful coexistence ${ }^{3}$, Bohr's suggestion resonated. After a period of isolation started in the $1930 \mathrm{~s}^{4}$, induced by Stalin's desire for economic and cultural autarky as well as the international context of the rise of Nazism, Soviet scientists received the concrete signal of the resumption of exchanges with foreign colleagues ${ }^{5}$. The desire for global peace of the 1950s opened up new prospects, especially as science had undergone an intense process of institutionalization at the international scale through the model of the International Council of Scientific Unions (ICSU). Established in 1931, this non-governmental confederation of national academies and international unions devoted

${ }^{1}$ Niels Bohr was notably one of the founding fathers of quantum theory.

${ }^{2}$ Bohr N. For an open world // Bulletin of the Atomic Scientists. 1950. Vol. 6, iss. 7. P.213-219. - On Bohr's concept of "open world", see also: Pasachoff N. E. Niels Bohr: Physicist and Humanitarian. Berkeley, 2003.

${ }^{3}$ Khrushchov N.S. Report of the Central Committee of the Communist Party of the Soviet Union to the $20^{\text {th }}$ Party Congress. M., 1956.

${ }^{4}$ The breakdown of scientific exchanges for Soviet physicists is notably discussed in: Josephson P.R. Physics and Soviet-Western Relations in the 1920s and 1930s // Physics Today. 1988. Vol. 414, iss. 9. P. 54-61.

${ }^{5}$ Different sources on the Soviet resumption of scientific relations from the 1950s are available. On Soviet international politics, one can consult: Mastny V. Soviet Foreign Policy, 1953-1962 // The Cambridge History of the Cold War. Vol. 1, Origins / eds M. P. Leffler, O. A. Wastad. Cambridge, 2010. P.312-333. Cultural exchange is discussed in: Richmond Y. Cultural Exchange and the Cold War. Raising the Iron Curtain. University Park, 2004. P.65-76. To what concerns more specifically science, see: Hollings C.D. Scientific Communication Across the Iron Curtain. Dordrecht, 2016. See also: Ivanov K. Science after Stalin: Forging a New Image of Soviet Science // Science in Context. 2002. Vol. 15, iss. 2. P.317-338. 
to specific disciplines developed itself when the newborn ${ }^{6}$ United Nations Educational Scientific Cultural Organization (UNESCO) recognized its role as a well-established body for the promotion of science - a formal agreement of cooperation was signed in December 1946 which offered financial and staff support ${ }^{7}$. The Soviet Union joined these institutions slightly later in $1954^{8}$.

However, the changes in the scientific world in the post-war period were also accompanied by political processes. During the Cold War, with the emergence of Truman and Zhdanov doctrines, international conflicts were reconsidered as struggles for political, economic and cultural domination. Meanwhile, science - more specifically, military and nuclear researches - had proven during the Second World War their potential to demonstrate the superiority of a country. Therefore, its rapid internationalization led to its being considered a key element of cultural diplomacy ${ }^{9}$. Recently, Roberto Lalli published a study that revealed many aspects of the issues raised by the transformation of science into a diplomatic tool ${ }^{10}$. Outlining the process of building of the community of general relativity and gravitation in the post-war period - from its birth in the 1950s, to its joining the International Union of Pure and Applied Physics (IUPAP), a member of the ICSU, in 1975 - he remarkably underlined that the institutional structure formed by the physicists was the result of different epistemic but also cultural, social and political tensions ${ }^{11}$. In his narrative, the historian notably focused on a conference organized in 1968 in Tbilisi. There, diplomacy manifested itself most unequivocally as for political reasons Israeli physicists were initially not invited to participate. An ideal conception of science, its neutrality, was challenged, provoking a major crisis which would influence structural reforms to come.

The present essay does not aim at discussing the results obtained by Lalli. But by shifting the focus we wish to highlight that this episode in the history of physics can also be considered more specific to the history of Soviet cultural diplomacy. The crisis of 1968 helps us to understand political influences on scientists in the USSR better. In this context, the archives of the Head of the local organizing committee of the Tbilisi conference, Vladimir A. Fock, are particularly valuable and have been used as our main source $^{12}$. In the first section of the article, after a short introduction with regard to the community in question, the focus will be on the course of events of the Tbilisi crisis and its consequences. The second section, exemplified in the analysis of the character of Fock, discusses the specificity of the relations between Soviet scientists and their authorities scientific and political - in an international context.

6 The UNESCO was founded on November 16, 1945.

7 On the ICSU, see: Greenaway F. Science International: A History of the International Council of Scientific Unions. Cambridge, 1996.

${ }^{8}$ Concerning the outward orientation of Soviet science and its joining international institutions, see: Ivanov K. Science after Stalin... P. 322-325.

9 Some speak of "science diplomacy". A good example of science as a diplomatic tool during the Cold War is Teasel Muir-Harmony's Ph.D. dissertation on the Project Apollo: Muir-Harmony T. Project Apollo, Cold War Diplomacy and the American Framing of Global Interdependence. Boston, 2014.

10 Lalli R. Building the General Relativity and Gravitation Community During the Cold War. Dordrecht, 2017.

11 Ibid. P. 129.

12 Arkhiv Rosiiskoi akademii nauk, Sankt-Peterburgskii filial (future - ARAN SPb). F. 1034. 


\section{Scientists Facing the Tbilisi Crisis}

\section{BERN 1955 - ROYAUMONT 1959: INSTITUTIONALIZATION}

The field of physics dealing with the theory of general relativity experienced a very peculiar dynamics known as its "Renaissance"13 in the post-war period. After a thirty-year period of stagnation following the elaboration and confirmation of the theor $y^{14}$, the 1950s marked its return to the mainstream of physics. It was notably accompanied by the establishment of an institutional framework, of which Lalli made a thorough study ${ }^{15}$. This process began in 1955 when, on the initiative of the Swiss physicist André Mercier, a scientific event to celebrate half a century of the formulation of the theory of special relativity by Albert Einstein was organized in Bern ${ }^{16}$. For the first time, specialists received the possibility to meet and to evaluate the state of the field. They met again in 1957 at Chapel Hill in the United States, and in 1959 at Royaumont in France. There, the most influential physicists gathered together with a view to creating the International Committee on the General Relativity and Gravitation (ICGRG) ${ }^{17}$. Its activity was defined as follows:

"The Committee's task would be to coordinate collaboration in scientific work in the field of General Relativity, Gravitation and related subjects, especially to help towards the organization of international Conferences and of other meetings of minor importance throughout the World, and to promote mutual information useful to all interested in the field"18.

A rotating presidency was set up, occupied by the Head of the local organizing committee of each previously held international conference. Since 1959 they were organized every three years. Initially, the ICGRG was composed of sixteen members, with Mercier as Secretary. It included two Soviets: Vladimir Fock (Leningrad State University) and Dmitri Ivanenko (Moscow State University).

\section{TBILISI 1968: THE ISRAELI CRISIS}

In 1965, during a conference in London, the ICGRG expressed to Fock the "general wish" that the following event be organized in the Soviet Union. Touched by this proposal, the Russian responded that he would do his best to ensure the conditions favorable to the realization of such a conference and to give an answer concerning its feasibility before the end of the year ${ }^{19}$. He was actually unable to take such a decision on his own and had to con-

13 The term "Renaissance" was introduced at the end of the 1980s by Clifford Will. See notably: Will C. The Renaissance of General Relativity // The New Physics / ed. by P.Davies. Cambridge, 1989. P. 7-33. More recent historiographical considerations on this process are developed by: Blum A., Lalli R. and Renn J. The Reinvention of General Relativity: A Historiographical Framework for Assessing One Hundred Years of Curved Space-time // Isis. 2015. Vol. 106. P. 598-620.

${ }^{14}$ Eisenstaedt J. La relativité générale à létiage: 1925-1955 // Archive for History of Exact Sciences. 1986. Vol. 35, iss. 2. P. 115-185.

${ }_{15}$ Lalli R. Building the General Relativity and Gravitation Community During the Cold War.

16 Ibid. P. 35-47.

17 Ibid. P. 47-53.

18 Mercier A., Schaer J. General Information // Bulletin on General Relativity and Gravitation. 1962. Iss. 1. P. 1-2.

19 Procès-verbal succinct des séances du Comité GRG tenues à Londres les 30 juin et 7 juillet 1965 // Library of the Max Planck Institute for the History of Science in Berlin. Papers of the International 
sult his scientific authorities in the USSR. They gave him full support as on October 1, he received a permission from the Academy of Sciences to organize an international conference in the summer of 1968, for which he could invite up to 250 foreign scientists ${ }^{20}$. Moreover, a letter of November 3 informs us that the Ministry of Higher Education also supported the event ${ }^{21}$. A local organizing committee was established with Fock as President, notably accompanied by A.Z. Petrov from Kazan University and I. M. Khalatnikov, Director of the Landau Institute for Theoretical Physics in Moscow - both had since been elected members of the ICGRG. As the city of Tbilisi was chosen, they were joined by M. M.Mirianashvili, Corresponding Member of the Georgian Academy of Sciences, and A.B. Kereselidze from Tbilisi State University, who served as Scientific Secretary. However trivial the choice of the Georgian capital may look - the physicist Vitali Ginzburg pointed out the tourist interest and the low cost for the participants ${ }^{22}-$ it is also reasonable to think that the organizers decided, above all, to rely on the know-how demonstrated during the organization of the second Soviet Conference on Gravitation on April 1965 in this place ${ }^{23}$. In short, everything was done to prepare a successful scientific event and a great celebration of Soviet science. But it turned out into a big crisis, after which the Israeli physicists that the ICGRG had wished to invite to Tbilisi were never able to attend the conference ${ }^{24}$.

It all began a year before with the Third Arab-Israeli War - known as the Six-Day War - between Israel and the neighboring states of Egypt, Jordan, and Syria in June 1967. One of its consequences was the sudden interruption of diplomatic relations between the USSR and Israel ${ }^{25}$. Then, as a result of international geopolitics, the Academy of Sciences of the USSR did not send formal invitations for the Tbilisi Conference to Israeli physicists: Nathan Rosen, Asher Peres, and Moshe Carmeli. Initially, their names were on the list of participants and speakers likely to be invited to Georgia that was drawn up at the meeting of the ICGRG held on June 22, 1967, in Paris ${ }^{26}$. But in May 1968, Peres alerted Peter Bergmann - an American member of the ICGRG - that none of the three aforementioned Israelis had received the precious invitation ${ }^{27}$. Bergmann informed the Briton, Hermann Bondi, who acted as President of the ICGRG, and asked him to intervene with Soviet colleagues to fix the situation ${ }^{28}$. On June $17^{29}$, he wrote to the four Soviet members of the ICGRG - Ginzburg, Petrov, Ivanenko, and Fock — urging them to send an invitation for

Society on General Relativity et Gravitation. I am grateful to Roberto Lalli who shared with me this document.

${ }^{20}$ V.A.Leshkovtsev (scientific secretary of the Department of Fundamental and Applied Physics of the USSR Academy of Sciences) to V. A. Fock. October 1, 1965 // ARAN SPb. F. 1034. Op. 2. D. 198.

${ }^{21}$ V. A. Kotel'nikov (Academician of the USSR Academy of Sciences) to V. A. Fock. November 3, 1965 // Ibid.

${ }^{22}$ Minutes of the Meeting held at New York. January 22, 1967 // Ibid.

23 On the Soviet conferences on gravitation see: Sardanashvili G. A. Dmitriy Ivanenko - superzvezda sovetskoi fiziki. M., 2014, P. 142-148. Ivanenko was the instigator of such events.

${ }^{24}$ To complete our considerations see: Lalli R. Building the General Relativity and Gravitation Community during the Cold War. P. 75-128.

25 See: Govrin Y. Israeli-Soviet relations, 1953-1967: from confrontation to disruption. London; Portland, 1998.

${ }^{26}$ Lalli consulted such lists and other documents in the personal archives of Peter Bergmann: Lalli R. Building the General Relativity and Gravitation Community During the Cold War. P. 78.

27 Ibid. P. 79. Peres to Bergmann. May 14, 1968.

28 Ibid. Bergmann to Bondi. May 17, 1968.

29 Bondi was initially hoping to meet Fock personally in Trieste, which explains the delay: The events of summer 1968 // Churchill College (CC). Bondi papers. BOND 4/4A. 
the conference to the three Israeli scientists ${ }^{30}$. His fear, shared by Bergmann, was that the omission was of a political nature and not the object of a mere administrative error. In the first case, it was the very holding of the conference that could be threatened ${ }^{31}$.

The situation could have been quickly resolved by simply sending the invitations to their recipients. However, Bondi's intuition proved to be correct, and the incident took a different turn. Over two months, the tension had never ceased to increase as the community faced its first major crisis. On July 12, Bondi addressed the issue to all members of the ICGRG. Clear deadlines were set:

"If [...] by August $23^{\text {rd }}$ we have not received any such notification we will send out telegrams to all members of the Committee stating "No invitation yet received by any Israeli colleague". If this is not countermanded by $2^{\text {nd }}$ September I propose that, with the agreement of the members of the Committee, our sponsorship of the Tbilisi Conference should be withdrawn and I myself would not in such a case go there"32.

Yet nothing had changed when on August 20, 1968, the Red Army and the troops from four other members of the Warsaw Pact - Bulgaria, Hungary, Poland and East Germany - entered Czechoslovakia to end the Prague Spring. In response, on August 26, André Mercier in a telegram recommended that the members of the ICGRG should not go to Tbilisi ${ }^{33}$. This radical action marked a real break from the neutrality generally required by his position of Secretary. Somehow cornered and without other recourse, on August 28, Bondi announced the withdrawal of the ICGRG support to the Tbilisi Conference. According to him, it could not "in the current state of affairs be considered truly international" 34 . The decision whether to go to Georgia or not, was left to everyone's discretion, however, the situation provoked a cascade of cancellations among physicists ${ }^{35}$.

It also brought about a Soviet reaction as five days before the beginning of the conference, on September 4, Peres received an official invitation ${ }^{36}$. Bondi then reacted and sent a telegram to restore the support of the ICGRG ${ }^{37}$. The situation was saved, but it looked like a stampede, especially since Peres did not receive the visa to reach Georgia on time ${ }^{38}$. Furthermore, the discomfort created by this situation was not without consequences. As Lalli pointed out: " [It] produced a series of resolutions that, if implemented, would have far-reaching consequences on the regulations governing the ICGRG and subsequent international conferences" 39 .

30 Bondi to Fock, Ginzburg, Ivanenko and Petrov. June 17, 1968 // ARAN SPb. F. 1034. Op. 2. D. 198.

${ }^{31}$ Ibid. See also: Bondi to Fock. July 3, 1968 // CC. Bondi papers. BOND 4/4A. Bondi explained in this telegram that "if people got the impression that there was a reluctance to invite these people on political grounds $\langle\ldots\rangle$ it could endanger the entire conference".

32 Bondi to the members of the ICGRG. July 12, 1968 // ARAN SPb. F. 1034. Op. 2. D. 198.

33 Mercier to the members of the ICGRG. August 26, 1968 // CC. Bondi papers. BOND 4/4A.

${ }^{34}$ Bondi to the members of the ICGRG. August 28, 1968 // Ibid.; ARAN SPb. F. 1034. Op. 2. D. 198.

35 Of special importance are the telegrams from Alfred Schild and Jules Geheniau (August 30, 1968), the letter from Roger Penrose (August 28, 1968) and from Peter Havas (August 29, 1968) requesting to Bondi the cancellation or postponement of the conference // CC. Bondi papers. BOND 4/4A.

36 Spaethe Esro, Kereselidze, and Ivanenko to Bondi. September 4, 1968; Peres to Bondi. September 5, 1968 // Ibid.

37 Bondi to Mercier, the organizers of the Tbilisi Conference, and the members of the ICGRG. September 6, 1968 // Ibid.

38 Peres to Bondi, Fock, Ivanenko, and Petrov. September 8, 1968 // ARAN SPb. F. 1034. Op. 2. D. 198.

39 Lalli R. Building the General Relativity and Gravitation Community during the Cold War. P. 87. 


\section{COPENHAGEN 1971: HIGH TENSIONS}

The specialists in the theory of relativity met again in 1971 in Copenhagen ${ }^{40}$. Among the subjects to be discussed there was the proposal made a few months earlier by Nathan Rosen to organize the next conference in Israel ${ }^{41}$. It was perceived by a part of the community as a fair form of compensation after Georgia. However, informed of the events in preparation, the Soviet delegation was ordered by the authorities to oppose $\mathrm{it}^{42}$. It happened on July 6, at the meeting of the ICGRG, when Rosen renewed his offer. Ivanenko and Fock immediately rose up against this idea. The first one emphasized diplomatic difficulties and "proposed to accept this invitation under the condition that the political affairs [were] settled within this year" ${ }^{33}$. On his side, Fock was more radical. For him: "...the Committee should abstain from political actions and that choice of Israel would be a political action, since Israel is in a state of war with his [sic!] neighbors" 44 . But these arguments were not accepted by their colleagues, who voted for holding the conference in Israel in 1974. It was the first defeat for the Soviets.

Indeed, more happened when a general assembly was convened two days later. It aimed at discussing a potential restructuring of the ICGRG to join the IUPAP ${ }^{45}$. Ivor Robinson, an American mathematical physicist of Jewish descent, took this occasion to criticize the 1968 Soviet failure in the Israeli case and "ask[ed] the whole General Assembly to express a regret at connecting political actions with scientific affairs by the Soviet Union" 46 . The tension was at its maximum. Ivanenko tried to intervene by asking Dennis Sciama, who chaired the assembly, to stop Robinson, but without effect. Then the Soviet delegation, feeling insulted, left the room, soon followed by a large majority of Polish and East German members ${ }^{47}$. The debates were heated as physicists like Bondi, Peres, and Bergmann expressed in turn their opinions. It was then that the Soviet scientist Vladimir Braginsky decided to join again the assembly with a desire of appeasement: " [he] explain [ed] in some words the organization of the Tiflis [sic!] Conference; at the same time, he urge[ed] the Chairman to bring the assembly to speak about scientific things" 48 . Only after Mercier proposed a motion - 43 voted in favor of it and 36 against — was it possible to come back to questions on the agenda.

${ }^{40}$ Ibid. P. 101-127. - Lalli's book develops in more detail different issues and consequences provoked by the decisions taken at this conference. Unfortunately, the folder dedicated to this event in Fock's archives does not provide any elements to shed light on our present narrative. In particular, the report that the physicist usually presented to the Ministry of Higher Education is not included (ARAN SPb. F. 1034. Op. 2. D. 198). M-A.

${ }^{41}$ Rosen to Mercier. March 24, 1971 // Niels Bohr Archives (NBA). GR6 papers. Correspondence

${ }^{42}$ See the testimony of Isaak Khalatnikov: Khalatnikov I. M. From the Atomic Bomb to the Landau Institute. Autobiography. Top Non-Secret. Dordrecht, 2012. P. 134.

${ }^{43}$ Minutes of the Meetings of the Committee on GRG held on the occasion of the GR6-Conference in Copenhagen // Personal archives of Georges Dautcourt (future - PAGD). - I greatly thank Roberto Lalli for letting me know the content of some documents of this collection.

${ }^{44}$ Ibid.

45 Minutes of the $1^{\text {st }}$ meeting of a General Assembly towards the foundation of a Society for General Relativity and Gravitation (PAGD).

46 Ibid.

47 See: Ivanenko to Møller. July 22, 1971 // NBA. GR6 papers. Correspondence A-L.

48 PAGD. 
Nevertheless, in the debates about the restructuring of the ICGRG, two national traditions contradicted each other. On the one hand, the younger generation, mainly American, was for turning the institution into a democratic scientific society whose leaders would be elected by all its members. On the other hand, the Soviets were privileging representation by national delegates, that would notably give more control to the Academy of Sciences of the USSR. However, weakened by the attack of Robinson and outnumbered, the Soviet delegation was unable to prevent the ICGRG from becoming a democratic society. The Academy lost its control on the choice of its representatives, and Copenhagen signified a complete snub for Soviet cultural diplomacy.

\section{Soviet Scientists' Relations with Their Authorities}

\section{VLADIMIR FOCK: THE PERFECT REPRESENTATIVE}

Soviet scientists were in the front line of cultural diplomacy, and many questions raised by the Tbilisi crisis concern their relations with authorities in the USSR. Vladimir Fock's central position during the crisis provides a remarkable case study of this issue. Indeed, he benefited from a privileged international trajectory in the post-war period. In addition, even the very reason for his presence in the ICGRG gives answers to the objectives and functions of Soviet science diplomacy.

Nowadays, Fock is a familiar name to many physicists, especially those involved into quantum theory and general relativity. As far as quantum theory is concerned, at the turn of the 1930s, Fock was the author of important contributions: the Hartree-Fock method of approximation for the determination of the wave function in many-body problems, and the Fock space, a mathematical tool used to describe quantum states in situations where the number of particles is not fixed

Later, in 1939 - year that saw him elected Academician of the USSR Academy of Science - he also contributed to the motion problem in general relativity and asserted himself as a world-class scientist. However, this factor cannot be considered as unique in understanding why he greatly benefited from the new changes in the Soviet science during the 1950s. Indeed, it has to be noted that at the beginning of the 1930s Fock became a supporter of dialectical materialism and then dedicated a good part of his work to questions of interpretation in physics. His goal was to demonstrate the compatibility of modern theories with the Marxist philosophy ${ }^{49}$. In particular, his materialist approach to general relativity led him to an unorthodox interpretation, which was well-received in the USSR ${ }^{50}$.

Fock was also active in debunking what he called the "ignorant criticism" of modern physics by some Soviet philosophers and argued that they were incapable of dealing

49 More in: Martinez J.-P. Vladimir Fock (1898-1974): itinéraire externaliste d'une pensée internaliste. Paris. 2017. See also Loren Graham's fundamental study of the role of Soviet ideology in science: Graham L.R. Science, Philosophy, and Human Behaviour in the Soviet Union. New York, 1987. P. 337-343 and 367-378.

${ }^{50}$ Ibid. (Martinez and Graham). See also: Gorelik G. E. Vladimir Fock: Philosophy of Gravity and Gravity of Philosophy // The Attraction of gravitation: new studies in the history of general relativity / eds J. Earman, M. Janssen, J. D. Norton. Boston, 1993. P. 308-331; Graham L. R. The Reception of Einstein's Ideas: Two Examples from Contrasting Political Cultures // Albert Einstein, Historical and Cultural Perspectives. The Centennial Symposium in Jerusalem, 14-23 March 1979 / eds G. Holton, Y.Elkana. Princeton, 1982. P. 107-136. 
with scientific subjects ${ }^{51}$. Most notably, he was regularly opposing the views of Aleksandr A.Maksimov, whose criticism was so strong that he sometimes called for the rejection of general relativity ${ }^{52}$. As far as that peculiar case was concerned, at the beginning of the 1950s Fock received the support of physicists working on the nuclear project ${ }^{53}$. They approved of his request for the publication of an article that would denounce Maksimov ${ }^{54}$. Politicians were also involved, such as Georgy M. Malenkov - Secretary of the Central Committee of the CPSU - and Lavrentiy P. Beria - Head of the Atomic Project and Deputy Premier of the Soviet Union ${ }^{55}$. They were ultimately responsible for publishing the article. Indeed, conscious of the role played by modern physics in the post-war period, but also satisfied with Fock's ideological response to philosophers, they gave credit to his words. Since then, the physicist's situation had changed, as summarized by Graham:

"In the late forties and early fifties Fock won the approval of the leaders of the regime, and he was rewarded with the right to travel widely in Europe and America. Soviet intellectuals were told in university classrooms and philosophical journals that V. A. Fock had cleansed relativity theory of the idealistic trappings placed upon it by bourgeois scientists and had developed a version of the theory that accorded thoroughly with Marxism" 56.

Then, Fock's new standing was confirmed by the authorities when he was chosen by the Academy of Sciences to lead the Soviet delegation at the 1955 Bern Conference on relativity ${ }^{57}$.

In Switzerland, his work received the attention of his colleagues, as proven by the English translation ${ }^{58}$ of a monograph on the theory of relativity that he was about to publish in the USSR ${ }^{59}$. Then the originality of his position combined with his reputation as a Soviet world-class physicist helped him to join the ICGRG in $1959^{60}$. Such activity was well received in the Soviet Union as clearly shown by the regular travels Fock made in the fol-

${ }^{51}$ Fock V.A. Protiv nevezhestvennoy kritiki sovremennykh fizicheskikh teoriy // Voprosy filosofii. 1953. No. 1. P.168-174.

52 Maksimov A. A. Protiv reaktsionnogo einshteinianstva v fizike // Krasnyi flot. 1952. June 14.

${ }^{53}$ On this important episode of the history of Soviet physics: Vizgin V.P. The nuclear shield in the 'thirty-year war' of physicists against ignorant criticism of modern physical theories // Physics-Uspekhi. 1999. Vol. 42, iss. 12. P. 1259-1283; Sonin S. A. Fizicheskii idealizm: Dramaticheskii put' vnedreniia revoliutsionnykh idei fiziki nachala XX veka (na primere istorii protivostoianiia v sovetskoy fizike). M., 2017.

${ }^{54}$ Fock V.A. Protiv nevezhestvennoi kritiki sovremennykh fizicheskikh teorii // Voprosy filosofii. 1953. No. 1. P. $168-174$.

55 More about the involvement of politicians in: Ilizarov S. S., Pushkareva L. I. Beriia i teoriia otnositel'nosti // Istoricheskii arkhiv. 1994. No. 3. P.215-223. Original letters are notably published in this article.

56 Graham L.R. The Reception of Einstein's Ideas: Two Examples from Contrasting Political Cultures // Albert Einstein, Historical and Cultural Perspectives. The Centennial Symposium in Jerusalem, 14-23 March 1979 / eds G. Holton, Y. Elkana. Princeton, 1982. P. 129.

${ }^{57}$ L. M. Brekhovskikh and E. A. Koridalin to Fock, October 25, 1954 // ARAN SPb. F. 1034. Op. 2. D. 198.

${ }^{58}$ Fock V.A. The Theory of Space, Time and Gravitation. London, 1959. In Bern, Wolfgang Pauli learned about the Russian edition in preparation and decided to get in touch with a British publishing house for an English version: Rosbaud to Rosenfeld, February 22, 1956 // NBA. Léon Rosenfeld Papers. Manchester. B.7. F. 6.

${ }^{59}$ Fock V.A. Teoriia prostranstva, vremeni i tiagoteniia. M., 1955.

60 Among the criteria retained for the selection of the members of the ICGRG, one finds in particular the authority in the field as well as the desire to represent different scientific and geographical sensitivities: Lalli R. Building the General Relativity and Gravitation Community during the Cold War. P.52-53. 
lowing years ${ }^{61}$, and the support he received to organize the Tbilisi Conference. But more was to happen than a simple reward to a physicist who had won the approval of the leaders of the regime. In the context of the development of cultural diplomacy, it appears that the theorist had also succeeded in playing the exact role of representative that was expected by the Soviet authorities. He fulfilled all the prerequisites for such a role, conjugating remarkable scientific competences with a form of allegiance to the main principles of the Soviet system. This last point manifested itself in his adherence to dialectical materialism, but it was also the case politically. Although he had never been a member of the Communist Party, some of his personal writings revealed a form of compliance ${ }^{62}$. Institutionally, Fock was also perfectly prepared to the heavy bureaucracy generated by the Soviet regime. His personal archives show traces of numerous interactions with the authorities, from travel reports for the Academy of Sciences and the Ministry of Higher Education to correspondence with the highest dignitaries, as already seen in his fight against Maksimov.

\section{TBILISI: INERT AUTHORITIES}

Fock's documents show a liberty of expression with both his colleagues and his scientific or political authorities. Therefore, an archive study helps us to better understand the true nature of the physicist's interactions with his superiors during the Tbilisi crisis as well as the course of the events ${ }^{63}$. In particular, it clarifies one of the main questions in that situation: the responsibility of the members of the Soviet organizing committee. Its Head, Fock, was informed of the nascent controversy during a scientific event in Trieste in June 1968 where he discussed the matter with colleagues, including Stanley Deser and Oskar Klein. The first later explained Bondi that for him "it was clear [Fock] neither wished nor intended to take any serious action re[garding] the Israelis" ${ }^{\prime 64}$. To be exact, the Soviet was initially in phase with the foreign policy of the USSR as he would explain to Kereselidze in a letter of July 13. Moreover, he even declared that: "Basically, my point of view is the following. I think we (i. e. the Soviet Organizing Committee) were right when we refrained from inviting Israeli Jews" ${ }^{\prime 6}$. Thus, at first, Fock's guilt seems evident. But this complacency for the regime does not reflect the exact process at work that Kereselidze established with more precision in his answer: the local organizing committee was not authorized to invite scientists from Israel ${ }^{66}$. Indeed, it was customary for the diplomatic bureau of the USSR Academy of Sciences to be the sole decision-maker when a list of foreign personalities was drawn.

Fock's passive approbation of the situation actually changed when he realized that the ICGRG would not accept it. His reputation and the success of the conference were in danger. This is why, upon returning from Trieste, he immediately took action to end the crisis: on July 1, he consulted the Vice-President of the Academy of Sciences, Ya. V. Peyve, in charge of international relations:

61 Poland in 1962, Italia in 1964, England in 1965, Germany in 1966 and France in 1967.

62 See, for example, his correspondence with the Dutch physicist Frederik Jozef Belinfante: ARAN SPb. F. 1034. Op. 3. D. 14, 251.

63 A folder is notably dedicated to the 1968 conference // ARAN SPb. F. 1034. Op. 2. D. 198.

64 Deser to Bondi, July 16, 1968 // CC. Bondi papers. BOND 4/4A.

65 Fock to Kereselidze, July 13, 1968 // ARAN SPb. F. 1034. Op. 2. D. 198.

66 Kereselidze to Fock, undated // Ibid. 
"I raised the issue with him, saying that maybe, to avoid provocations and attempts by Jews from different countries to undermine the success of the conference it would be necessary to satisfy the request of Klein / who plays an important role in the Nobel Committee / and invite a person from Israel"67.

It followed that this very day, Fock was instructed by his interlocutor to write an invitation to Asher Peres ${ }^{68}$. He entrusted the document to S. G. Korneev, Head of the International Department of the Academy of Sciences, but sending it still required authorization from "higher authorities" 69 . This process then highly complicated the situation. Present in Moscow between July 16 and 18, Kereselidze learned that the chances of the invitation being sent before the end of the month were limited ${ }^{70}$. Khalatnikov shared this feeling in a letter to Fock on July $24^{71}$. Other actions were probably taken, but we only know from the archives that on August 28 Fock was still in discussion with the Academy concerning the sending of the precious invitation ${ }^{72}$. It was the day before Bondi announced the withdrawal of the ICGRG support to the conference.

As it had been mentioned before, this last event was probably the real trigger of the reaction of the Soviet authorities. But until then, for two months already, Fock and his colleagues had been dealing with the inertia of the Academy of Sciences. Very cautious in political matters, the main scientific institution in the USSR let them be suspended by the decision of "higher authorities" at the end of an interminable bureaucratic chain. Despite multiple reminders, it appears that nobody was willing to take a decision perceived as an important political gesture. In this context, the withdrawal of the ICGRG support left the Academy in a diplomatic dead end. Thus, it appears to us that such an episode illustrates how people like Fock, despite their scientific authority and liberty of expression, were somehow powerless in front of the Soviet system.

\section{FOCK VERSUS IVANENKO: LIMITED INFLUENCE}

In the background there is also a plot of a different kind that supports our previous considerations and develops aspects of the relations between scientists and the Soviet power: Fock's enmity for Ivanenk $\mathrm{o}^{73}$. Its origins remain unclear and will not be discussed here $^{74}$, but it was clear that the physicist of Leningrad was dissatisfied with the presence

67 Fock to Kereselidze, July 13, 1968 // ARAN SPb. F. 1034. Op. 3. D. 198.

${ }^{68}$ For Fock. Peres remained the only possible Israeli candidate to invite. Rosen had excluded himself, announcing in a letter of September 1967 that he would not go to Georgia "in view of the extreme and completely one-sided anti-Israel policy that has been adopted by the Soviet Government as regards anti-semitism and a by-product of this policy" (Rosen to Mercier, copy to the members of the International Committee, September 4, 1967 // ARAN SPb. F. 1034. Op. 2. D. 198). As far as Carmeli is concerned, Fock considered he had an insufficient scientific level (Bondi to the members of the ICGRG, July 12, 1968 // ARAN SPb. F. 1034. Op. 2. D. 198).

Fock considered he had an insufficient scientific level (Bondi to the members of the ICGRG, July 12, 1968 // ARAN SPb. F. 1034. Op. 2. D. 198).

${ }^{69}$ Fock to Kereselidze, July 13, 1968 // Ibid.

70 Kereselidse to Fock, undated // Ibid.

${ }^{71}$ Khalatnikov to Fock, July 24 // Ibid.

72 Draft letter from Fock to Kereselidze, August 28, 1968 // Ibid.

${ }^{73}$ More in: Martinez J.-P. Vladimir Fock (1898-1974)... See also: Sardanashvili G. A. Dmitriy Ivanenko - superzvezda sovetskoy fiziki.

${ }^{74}$ One can consult: Snygg J. A New Approach to Differential Geometry using Clifford's Geometric Algebra. New York, 2012. P. 174-179. 
of his colleague from Moscow in the ICGRG. Fock considered that Ivanenko had been admitted only "at its own insistence" but also that "[the ICGRG was] fully aware of his scientific incapacity and [sought] to get rid of him"75. According to the first, a step in this direction was taken when on July 31, 1962, the ICGRG decided to include Aleksei Z.Petrov as one of its members, even though he did not speak foreign languages, and to no longer maintain correspondence with Ivanenko ${ }^{76}$. In 1968, in Tbilisi, Fock even tried - without success - to replace him by Ludvig D. Faddeev ${ }^{77}$. Such a move would have rewarded several years of attempts to discard Ivanenko from international activities related to general relativity.

In the USSR, Ivanenko was active in this field. In particular, he was the instigator in 1961 of a Soviet conference on gravitation, the first in a long series ${ }^{78}$. On August 25, 1962, Fock received a request from Lev A. Artsimovich of the Physico-Mathematics Department of the Academy of Sciences to give his opinion on an eleven-page report by Ivanenko, delivering a review of the state of research in the theory of gravitation in the Soviet Union, initially addressed to Khrushchev himself ${ }^{79}$. In response, Fock simply summarized all his grievances against his colleague. The tone was scathing:

"The so-called "professor" Ivanenko is not so much a scientist, but rather a speculator, a largescale speculator (the proof of this, otherwise, is in itself in his letter to N.S. Khrushchev). As is well known to physicists, who are part of the department of physico-mathematical sciences, Ivanenko has no independent scientific work but relies on self-praise for works actually done by others, which in the best cases allow him to put his name as a co-author"80.

To amplify his remarks on Ivanenko's work and personality, Fock continued by referring to the ICGRG Conference on General Relativity and Gravitation held in Poland in 1962. There the American physicist Richard Feynman notably humiliated Ivanenko by pointing out his mathematical incompetence ${ }^{81}$, but different events also took place:

“... during the Warsaw mission for the conference of 25-31 July, D. D. Ivanenko received from the Ministry of Higher Education all the funds allocated to the mission, and further appropriated funds awarded by the Polish Academy of Sciences to one of the three members (Zharkov) of the delegation of Soviet academicians (V. Fock, V. Ginzburg, G. Zharkov), leaving G. Zharkov without resources. At Petrov's request to return the money to Zharkov, Ivanenko said he had lost it. Thus, D. D. Ivanenko, to put it simply, stole from his comrade" 82 .

${ }^{75}$ Fock to Artsimovich, September 6, 1962 // ARAN SPb. F. 1034. Op. 2. D. 111.

76 Ibid. As Fock mentioned it, this decision had an unofficial character.

77 A draft letter from Fock to Kereselidze informs us of the intention to replace Ivanenko by Faddeev. August 28, 1968 // ARAN SPb. F. 1034. Op. 2. D. 198.

78 See: Sardanashvili G. A. Dmitriy Ivanenko - superzvezda sovetskoy fiziki. P. 142-152.

79 Report on the state of research in the theory of gravitation in the USSR sent by Ivanenko to Khrushchev, July 10, 1962. Copy sent to Fock on August 25, 1962 // ARAN SPb. F. 1034. Op. 2. D. 111.

80 Fock to Artsimovich. September 6, 1962 // Ibid.

81 On this episode see: Schucking E. L. Views from a distant past / General Relativity and Gravitation, 1989: Proceedings of the $12^{\text {th }}$ International Conference on General Relativity and Gravitation // eds N. Ashby, D. Bartlett, W. Wyss. Cambridge, 1990. P. 483.

${ }^{82}$ Fock to Artsimovich. September 6, 1962 // ARAN SPb. F. 1034. Op. 2. D. 111. 
Back from Warsaw, Fock described these events in his report on the Polish conference to the Academy ${ }^{83}$. Dated by August 7, 1962, it was also signed by Ginzburg and Zharkov, enhancing its credibility. Thus, when he answered Artsimovich a month later, Fock clearly considered Ivanenko an individual "scientifically and morally dishonest" and denounced his report to Khrushchev as nothing more than "a great fraud aimed at acquiring unrealistic advantages" 84 .

Fock's letter actually summarizes the arguments used on different occasions to convince the authorities of removing Ivanenko from activities related to the field of relativity. It was the case in the Soviet Union for the local organizing committee of the 1968 Tbilisi Conference ${ }^{85}$, but also for events abroad. As soon as in 1961, before the Warsaw Conference, Fock had already written to the Academy of Sciences and the Ministry of Higher Education to ask them to forbid Ivanenko to go to Poland ${ }^{86}$. In 1964, he renewed such a request after having learned the will of his colleague to go to Italy for the celebrations of the 400 years of Galileo. On April 7, in a letter to the Ministry of Higher Education, Fock pointed out the "highly undesirable" nature of such a possibility ${ }^{87}$. A week later, Mikhail A. Prokofiev, the USSR Deputy Minister of Higher and Specialized Education, responded positively to this demand ${ }^{88}$. However, as Fock would experience it again in 1968, the Soviet decision-chain was long and complex. Prokofiev did not have the final word, and Ivanenko went to Italy as he had gone to Poland two years before. Despite the efforts of the physicist of Leningrad with the authorities, his long argumentation, and the support of colleagues - as Ginzburg in the Zharkov affair - nothing worked. Ivanenko continued to travel, remained a member of the ICGRG, and played an important role in the Soviet institutions. Indeed, he was Vice-President of the Commission on Gravitation of the Ministry of Higher Education, a position he held from its creation on May 19, 1962, until its dissolution in $1989^{89}$.

The fact that Fock was a scientific authority in the field of general relativity, and that he succeeded in the early 1950s in establishing trustworthy relationship with the Soviet regime did not make him a decision-maker. It remained the unique property of political authorities. In the context when cultural diplomacy was considered the new way for a country to express its power, Fock was simply propelled to the role of a representative. It offered him privileges, such as the possibility to travel abroad, but also responsibilities. Indeed, he had now to deal with political objectives. To fulfill this agenda, the Professor from Leningrad had a small margin of maneuver, especially as he was facing the inertia and the lack of transparency of the Soviet bureaucracy. And actually, the irony of the story is that after the events of 1971 in Copenhagen - although he had fought to preserve the Soviet interests even in a more radical way than Ivanenko - he himself was removed from

83 Otchet o poezdke delegatsii AN SSSR na konferentsiiu po relativistskim teoriiam gravitatsii v Varshave // ARAN SPb. F. 1034. Op. 2. D. 184.

${ }^{84}$ Fock to Artsimovich. September 6, 1962 // ARAN SPb. F. 1034. Op. 2. D. 111.

85 "I must point out that the inclusion of Ivanenko in the organizing committee certainly hinders his work; in no case can this person take part in the direction of the committee". Fock to the Ministry of Higher Education. March 29, 1966 // ARAN SPb. F. 1034. Op. 2. D. 198.

${ }^{86}$ Fock to Artsimovich. September 6, $1962 / /$ ARAN SPb. F.1034. Op. 2. D.111. See also: Fock to Prokofiev. July 6, 1961 // ARAN SPb. F. 1034. Op. 2. D. 184.

87 Fock to Elyutin. April 7, 1964 // ARAN SPb. F. 1034. Op. 2. D. 190.

88 Prokofiev to Fock. April 14, 1964 // Ibid.

89 Sardanashvili G. A. Dmitriy Ivanenko - superzvezda sovetskoy fiziki. P. 186. 
the ICGRG activities. An investigation was conducted in the USSR, and Fock was judged, if not directly responsible for the situation, at least unable to cope with the international situation ${ }^{90}$. Never again he would be allowed to leave the Soviet territory.

\section{Concluding Remarks}

In 1968, as it was the tradition, Fock had been elected President of the ICGRG. It was somehow the peak of his career, but also the beginning of his fall as his reputation suffered after the Israeli crisis. Ivor Robinson, who attacked the Soviet organizers in Copenhagen, wrote a virulent letter to Mercier in 1969 expressing his indignation: "[Fock should] spare himself and all of us much embarrassment by a prompt and graceful resignation [from the presidency of the Committee], [because he had been unable to] abstain from gross discrimination against our Israel colleagues" ${ }^{\prime 1}$. In other words, for Robinson, Fock was guilty of having flouted the fundamental principle of the neutrality of science ${ }^{92}$. In Tbilisi, the physicists faced the reality of a world where geopolitical issues took precedence over science. They were torn apart by such a situation. Then while public declarations and collective decisions were conducive to appeasement, individual reactions to the events were divergent.

The attitude of Fock is an illustration of this. Individually, he used pragmatic and strategic arguments. For example, he mentioned the role played by the Jewish Oskar Klein in the Nobel Committee to stress the necessity to solve the situation ${ }^{93}$. In addition, he also claimed that for political reasons it was impossible to treat Israeli scientists equally to American ones, even if the USA was also at war with Vietnam at this period ${ }^{94}$. However, when the ICGRG met in assembly at the end of the Tbilisi Conference, Fock supported a motion stating that "every international conference is open to all" 95 . Another example is André Mercier, who later acknowledged that "it is a mistake to want to separate science and morality completely" ${ }^{\prime 6}$. Nevertheless, he also offered to resign as Secretary, as he recognized that the action he was engaged in personally, i.e., the telegram sent in reaction to the Prague Spring ${ }^{97}$, conflicted with his position ${ }^{98}$.

To summarize, as stated by Roberto Lalli, "there was the problem of the demarcation between principles and actions"99. And in an authoritarian regime like the Soviet one, the example of Fock shows us that scientists had in the end very little power of decision. Their actions were under control of their scientific and political authorities, and without a doubt, it led to a direct negation of the principle of neutrality in 1968. Some studies, as

90 See: Khalatnikov I. M. From the Atomic Bomb to the Landau Institute... P. 135.

91 Robinson to Mercier. April 5, 1969. Cited in: Lalli R. Building the General Relativity and Gravitation Community During the Cold War. P.92-93.

${ }^{92}$ For a discussion of this value traditionally attributed to science see: Douglas H. Science, Policy, and the Value-Free Ideal. Pittsburgh, 2009.

${ }_{93}$ Fock to Kereselidze. July 13, 1968 // ARAN SPb. F. 1034. Op. 2. D. 198.

94 Ibid.

${ }_{95}$ Minutes of the meeting of the International Committee on Gravitation and General Relativity. September 21, 1968 // ARAN SPb. F. 1034. Op. 2. D. 178; CC. Bondi papers. BOND 4/4A.

${ }_{96}$ Mercier to Fock. October 3, $1968 / /$ CC. Bondi papers. BOND 4/4A.

97 Mercier to the members of the ICGRG. August 26, 1968 // Ibid.

98 Mercier to Fock. October 3, 1968 // Ibid.

99 Lalli R. Building the General Relativity and Gravitation Community During the Cold War. P. 92. 
Ivanov's considerations on science after Stalin ${ }^{100}$, put forward the success encountered by Soviet scientists in the post-war period. In particular, while the USSR was opening itself to the exterior, they not only dropped such a Stalinist feature as the "party-mindedness" of science, but also softened the necessity of planning, and redefined the connection between science and practice. Undoubtedly, the ideological pressure on physicists faded, and such a process can partially explain why Fock, initially chosen in the 1950s for his capacity to deal with questions of interpretations in modern physics turned out to be less essential to the regime in the 1970s. However, this article also shows that one of the consequences scientists suffered was an increase in the political pressure at the international scale. To be a representative abroad and to fulfill the prerequisites of the Soviet cultural diplomacy implied new responsibilities. Thus, it was, above all, an event of political nature that cost Fock his privileged position.

While the context of the Cold War coincided with the most intense period of international institutionalization of science, cultural diplomacy gradually embraced scientific research. Therefore, it became clear that the "open world" envisioned by Niels Bohr applied to nuclear weapons or the field of general relativity - could not avoid difficulties caused by geopolitics. The Soviet Union played a leading role in this direction, and the peculiar relations it cultivated between scientists and their authorities only goes to show how science can become a powerful political object. However, as the debates on the transformation of the ICGRG into a democratic society demonstrated, it was not an exception as conflicting world conceptions were opposing each other. And nowadays, more than ever, the expansion of big science and research networks makes the issues posed by the treatment of scientific research as a tool of cultural diplomacy relevant.

\section{References}

Bohr N. For an Open World. Bulletin of the Atomic Scientists, 1950, vol. 6, iss. 7, pp. 213-219.

Blum A., Lalli R. and Renn J. The Reinvention of General Relativity: A Historiographical Framework for Assessing One Hundred Years of Curved Space-time. Isis, 2015, vol. 106, pp. 598-620.

Douglas H. Science, Policy, and the Value-Free Ideal. Pittsburgh, Pittsburgh University Press, 2009,210 p.

Eisenstaedt J. La relativité générale à l'étiage: 1925-1955. Archive for History of Exact Sciences, 1986, vol. 35, iss. 2, pp. 115-185.

Fock V.A. Protiv nevezhestvennoi kritiki sovremennykh fizicheskikh teorii. Voprosy filosofii, 1953, no. 1, pp. 168-174. (In Russian)

Fock V. A. Teoriya prostranstva, vremeni i tyagoteniya. Moscow, Gostekhizdat, 1955, 504 p. (In Russian)

Fock V. A. The Theory of Space, Time and Gravitation. London, Pergamon Press, 1959, $412 \mathrm{p}$.

Gorelik G. E. Vladimir Fock: Philosophy of Gravity and Gravity of Philosophy. The Attraction of Gravitation: New Studies in the History of General Relativity. Eds J. Earman, M. Janssen and J. D. Norton. Boston, Birkhauser, 1993, pp. 308-331.

Govrin Y.Israeli-Soviet Relations, 1953-67: From Confrontation to Disruption. London; Portland, Franck Cass, 1998, 347 p.

Graham L. R. Science, Philosophy, and Human Behaviour in the Soviet Union. New York, Columbia University Press, 1987, 565 p.

Graham L. R. The Reception of Einstein's Ideas: Two Examples from Contrasting Political Cultures. Albert Einstein, Historical and Cultural Perspectives. The Centennial Symposium in Jerusalem, 14-23 March 1979. Eds G. Holton, Y. Elkana. Princeton, Princeton University Press, 1982, pp. 107-136.

Greenaway F. Science International: a History of the International Council of Scientific Unions. Cambridge, Cambridge University Press, 1996, 292 p.

Hollings C. D. Scientific Communication Across the Iron Curtain. Dordrecht, Springer, 2016, 123 p.

100 Ivanov K. Science after Stalin... P. 317-338. 
Ilizarov S. S. and Pushkareva L. I. Beriiaa i teoriiaa otnositel'nosti. Istoricheskii arkhiv, 1994, no. 3, pp. 215223. (In Russian)

Ivanov K. Science after Stalin: Forging a New Image of Soviet Science. Science in Context, 2002, vol. 15, iss. 2, pp. 317-338.

Josephson P. R. Physics and Soviet-Western Relations in the 1920s and 1930s. Physics Today, 1988, vol. 414, iss. 9, pp. 54-61.

Khalatnikov I. M. From the Atomic Bomb to the Landau Institute. Autobiography. Top Non-Secret. Dordrecht, Springer, 2012, $213 \mathrm{p}$.

Khrushchev N.S. Report of the Central Committee of the Communist Party of the Soviet Union to the $20^{\text {th }}$ Party Congress. Moscow, Foreign Languages, 1956, 267 p.

Lalli R. Building the General Relativity and Gravitation Community during the Cold War. Dordrecht, Springer, 2017, $168 \mathrm{p}$.

Martinez J.-P. Vladimir Fock (1898-1974): itinéraire externaliste d’une pensée internaliste. Antiréductionnisme et réalisme scientifique en physique moderne. $\mathrm{PhD}$ in Epistemology and History of Science. Université Paris 7 - Paris Diderot, Paris, 2017, 581 p.

Mastny V.Soviet Foreign Policy, 1953-1962. The Cambridge History of the Cold War. Vol. 1, Origins. Eds M. P. Leffler, O. A. Wastad. Cambridge, Cambridge University Press, pp. 312-333.

Mercier A., Schaer J. General Information. Bulletin on General Relativity and Gravitation, 1962, iss. 1, pp. 1-2.

Muir-Harmony T. Project Apollo, Cold War Diplomacy and the American Framing of Global Interdependence. $\mathrm{PhD}$ in History, Anthropology, and Science, Technology and Society (HASTS). Massachusetts Institute of Technology, Program in Science, Technology and Society. Boston, 2014, 265 p.

Pasachoff N.E. Niels Bohr: Physicist and Humanitarian. Berlekey, Enslow, 2003, 128 p.

Richmond Y. Cultural Exchange and the Cold War. Raising the Iron Curtain. University Park, The Pennsylvania State University Press, 2004, 264 p.

Sardanashvili G. A.Dmitriy Ivanenko - superzvezda sovetskoi fiziki. Moscow, URSS / Librokom, 2014, 320 p. (In Russian)

Schucking E. L. Views from a Distant Past. General Relativity and Gravitation, 1989: Proceedings of the $12^{\text {th }}$ International Conference on General Relativity and Gravitation. Eds N. Ashby, D. Bartlett, W. Wyss. Cambridge, Cambridge University Press, 1990, pp. 479-490.

Snygg J.A New Approach to Differential Geometry using Clifford's Geometric Algebra. New York, Springer, 2012, 464 p.

Sonin S. A. Fizicheskii idealizm: Dramaticheskii put' vnedreniia revolyutsionnykh idei fiziki nachala XX veka (na primere istorii protivostoianiia $v$ sovetskoi fizike). Moscow, Lenand, 2017, 318 p. (In Russian)

Vizgin V.P. The Nuclear Shield in the "Thirty-year war" of Physicists Against Ignorant Criticism of Modern Phydical Theories. Physics-Uspekhi, vol. 42, iss. 12, pp. 1259-1283.

Will C. The Renaissance of General Relativity. The New Physics. Ed. by P. Davies. Cambridge, Cambridge University Press, 1989, pp. 7-33.

Received: August 29, 2018

Accepted: November 30, 2018

Статья поступила в редакцию 29 августа 2018 г. Рекомендована в печать 30 ноября 2018 г. 